\title{
Nitroxide-Mediated Polymerization of Vinyl Chloride at Low Temperature: Kinetic and Computational Studies
}

Carlos M. R. Abreu,${ }^{\dagger}$ Patrícia V. Mendonça,${ }^{\dagger}$ Arménio C. Serra,${ }^{\dagger}$ Benjamin B. Noble,${ }^{\ddagger}$ Tamaz Guliashvili, *\$ Julien Nicolas, ${ }^{*} \|$ Michelle L. Coote** and Jorge F. J. Coelho*†

${ }^{\dagger}$ CEMUC, Department of Chemical Engineering, University of Coimbra, 3030-790 Coimbra, Portugal

$\$$ ARC Centre of Excellence for Free-Radical Chemistry and Biotechnology, Research School of Chemistry, Australian National University, Canberra ACT 2601, Australia

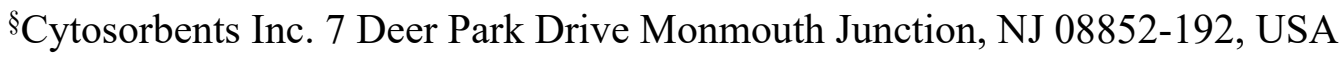

|| Institut Galien Paris-Sud, CNRS UMR 8612 , Univ Paris-Sud, Faculté de Pharmacie, 5 rue Jean-Baptiste Clément , F-92296, Châtenay-Malabry cedex , France

Keywords: reversible deactivation radical polymerization, nitroxide-mediated polymerization, low temperature, vinyl chloride, poly(vinyl chloride), block copolymer

\begin{abstract}
The synthesis of poly(vinyl chloride) (PVC) by nitroxide-mediated polymerization (NMP) using the SG1-based BlocBuilder alkoxyamine at low temperature (30 and $42{ }^{\circ} \mathrm{C}$ ) is reported. The reaction system was studied regarding the nature of the solvent, the monomer-to-solvent ratio, the polymerization temperature and the target molecular weight. First order kinetics and linear evolutions of the molecular weight with vinyl chloride (VC) conversion were obtained in dichloromethane (DCM) and dimethyl
\end{abstract}


sulfoxide (DMSO) together with decreasing dispersities $(\nexists)$ down to 1.59-1.47. The resulting PVC was fully characterized by ${ }^{1} \mathrm{H}$ nuclear magnetic resonance spectroscopy ( $\left.{ }^{1} \mathrm{H}-\mathrm{NMR}\right),{ }^{31} \mathrm{P}-\mathrm{NMR}$ and size exclusion chromatography (SEC). The ${ }^{1} \mathrm{H}-\mathrm{NMR}$ and ${ }^{31} \mathrm{P}-$ NMR revealed the existence of very small content of structural defects and the presence of chain-end functional groups ( $\sim 91 \%$ SG1 chain-end functionality). Chain extension experiments were performed with VC, methyl methacrylate (MMA) and mixture of monomers $(90 \%$ of MMA and $10 \%$ of styrene (S)) and confirmed the "livingness" of the PVC-SG1 macroinitiators, giving access to different PVC-based block copolymers. High level ab initio molecular orbital calculations suggested that the C-O bond in the PVCSG1 alkoxyamine is too strong to mediate the NMP of VC by simple "classic" activationdeactivation equilibrium, and is likely being mediated by a SG1-mediated dehydrochlorination mechanism. The results presented in this study established a new route to afford a wide range of new complex macrostructures based on PVC segments.

\section{Introduction}

In the past two decades, reversible deactivation radical polymerization (RDRP) methods have revolutionized the field of polymer synthesis. These approaches enable the facile design of polymers with a stringent control over their structures, their functionalities and their architectures using radical-based mechanisms. ${ }^{1}$ Among the different RDRP methods, atom-transfer radical polymerization (ATRP), ${ }^{1 e, f, 2}$ reversible additionfragmentation chain transfer $(\mathrm{RAFT})^{1 \mathrm{~b}-\mathrm{d}, 3}$ polymerization and nitroxide-mediated polymerization $(\mathrm{NMP})^{1 \mathrm{a}, 4}$ remain the most popular. Nowadays, it is possible to control the polymerization of a very broad range of monomer families (e.g., styrenics, acrylates, methacrylates, 1,3-dienes, etc.) using RDRP methods with certain ease and under rather mild experimental conditions. An immense part of the research effort has been focused on the development of more efficient control agents, ${ }^{1 \mathrm{a}, \mathrm{b}}$ more active catalysts ${ }^{5}$ and more environmentally friendly polymerization reactions ${ }^{6}$ (e.g., green solvents, ${ }^{7}$ mild reaction temperatures, ${ }^{8}$ etc.). Despite all these achievements, RDRP of non-activated monomers (e.g., vinyl acetate, VC, $N$-vinylpyrrolidone) remains enormously challenging. Poly(vinyl chloride) (PVC) is one of the highest volume polymers ( $\sim 39.3$ million tons in 2013$)^{9}$ and can only be prepared on an industrial scale by free-radical polymerization (FRP). ${ }^{10}$ Several features of VC make its control by RDRP methods particularly challenging, such 
as: (i) a very high reactivity $\left(k_{p, \mathrm{VC}}=11 \times 10^{3} \mathrm{~L} \mathrm{~mol}^{-1} \mathrm{~s}^{-1}\left(\right.\right.$ at $\left.50^{\circ} \mathrm{C}\right) ; k_{p, \mathrm{MMA}}=0.51 \times 10^{3} \mathrm{~L}$ $\mathrm{mol}^{-1} \mathrm{~s}^{-1}\left(\right.$ at $\left.\left.60{ }^{\circ} \mathrm{C}\right)\right) ;{ }^{11}$ (ii) an unusually high chain transfer constant to the monomer $\left(\mathrm{C}_{\mathrm{M}, \mathrm{VC}}\right.$ $=10.8-16 \times 10^{-4} ;{ }^{12} \mathrm{C}_{\mathrm{M}, \mathrm{MMA}}=0.07-0.25 \times 10^{-4}$, values at $60^{\circ} \mathrm{C}$ ) ${ }^{13}$ and (iii) the non-solubility of PVC in its monomer as well as in most common organic solvents. ${ }^{14}$

Some attempts to produce PVC by RDRP methods have been reported, namely by single electron transfer living radical polymerization (SET-LRP), ${ }^{15}$ single electron transfer degenerative chain transfer living radical polymerization (SET-DTLRP), ${ }^{14,16}$ cobaltmediated radical polymerization (CMRP) ${ }^{17}$ supplemental activator and reducing agent (SARA) ATRP ${ }^{7 a, 8 a}$ and RAFT. ${ }^{10}$ However, the study of other RDRP techniques facilitates a deeper understanding of VC polymerization and broadening the number of PVC-based macromolecular structures could have valuable synthetic utility. NMP is particularly appealing for VC polymerization, because of the simplicity of this protocol (an alkoxyamine, a 2-in-1 molecule, releases both the initiator and the control agent upon heating), the robustness of the process, the broad range of monomers that can be polymerized by this method and the absence of residual catalysts, color or toxic moieties. $^{\text {1a }}$

Braun and co-workers ${ }^{18}$ investigated the nitroxide-mediated suspension polymerization of $\mathrm{VC}$ at $70^{\circ} \mathrm{C}$ using various nitroxides including 2,2,6,6-tetramethylpiperidin-1-yloxyl (TEMPO) and (di-tert-butyl nitroxide) DBN, and reported low polymerization rates and high $Ð$ values $\sim 2$. Additionally, no information regarding the structural characteristics of the resulting PVC was provided. This information would be of particular relevance regarding the impact of temperature on the formation of structural defects that result from various unavoidable side reactions. ${ }^{14,19}$ Importantly, the presence of these unwanted structures has been shown to be the major cause for the low thermal stability of PVC. ${ }^{20}$

In this context, we report for the first time the NMP of $\mathrm{VC}$ using the commercially available SG1-based alkoxyamine, BlocBuilder, earlier termed MAMA-SG1 (Scheme 1). ${ }^{1 \mathrm{a}, 21}$ MAMA-SG1 has one of the highest dissociation rate constants $\left(k_{\mathrm{d}}=0.34 \mathrm{~s}^{-1}\right.$ at 120 ${ }^{\circ} \mathrm{C}$ ) among commercially available alkoxyamines making it attractive for the polymerization of monomers such as VC with less stabilized propagating radicals. Moreover, considering the high occurrence of side reactions (e.g., chain transfer to monomer) at elevated temperatures $\left(>60{ }^{\circ} \mathrm{C}\right)$ for the polymerization of $\mathrm{VC}$, we have chosen to conduct NMP of VC at $42{ }^{\circ} \mathrm{C}$, as a known standard temperature for VC RDRP. 
Another advantage of using the BlocBuilder alkoxyamine relies on the presence of a carboxylic acid group attached to the initiating moiety, which provides a convenient route for further PVC modifications to afford complex macrostructures using well-known coupling protocols. ${ }^{1 \mathrm{a}, 22}$

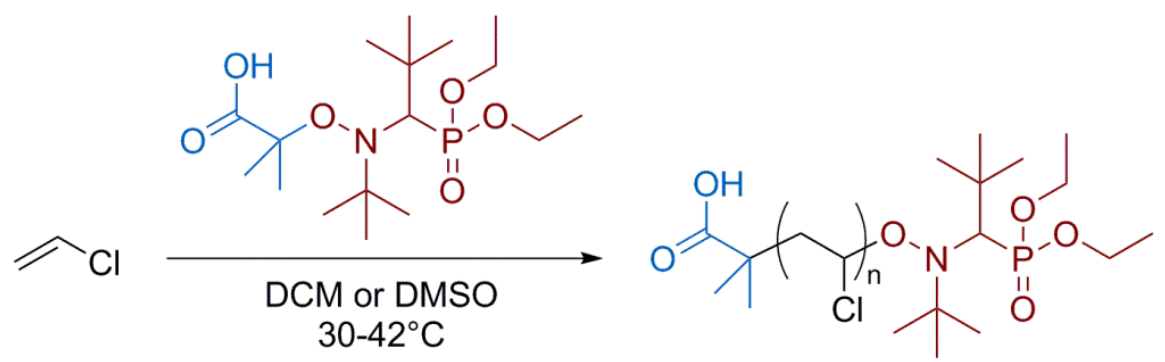

Scheme 1. General scheme and conditions for the NMP of VC initiated by the SG1-based BlocBuilder alkoxyamine.

\section{Experimental section}

\subsection{Materials}

VC (99.9\%) was kindly supplied by CIRES Lda, Portugal. MMA (99\% stabilized; Acros) and S (+ $99 \%$; Sigma-Aldrich) were passed over a basic alumina column before use to remove the radical inhibitors. The BlocBuilder alkoxyamine $(99 \%$, recrystallized before use) and the SG1 nitroxide (85\%) were kindly supplied by Arkema. Dichloromethane (DCM) (Fluka, HPLC grade), DMF (Sigma-Aldrich, $+99.8 \%$ ), DMSO (Acros, $+99.8 \%$ extra pure), THF (Panreac, HPLC grade), cyclohexanone (Sigma-Aldrich, 99.8\%), were distilled before use. Deuterated tetrahydrofuran ( $\mathrm{d}_{8}$-THF) (Euriso-top, 99.5\%), sulfolane (+99\%; Acros), 1-butyl-3-methylimidazolium hexafluorophosphate (BMIM-PF $6,>98 \%$; TCI (Tokyo Chemical Industry Co. LTD), methanol (Labsolve, 99,5\%) and polystyrene (PS) standards (Polymer Laboratories) were used as received.

\subsection{Techniques}

$600 \mathrm{MHz}{ }^{1} \mathrm{H}-\mathrm{NMR}$ spectra of samples were recorded on a Varian VNMRS $600 \mathrm{MHz}$ spectrometer, with a $3 \mathrm{~mm}$ PFG triple resonance indirect detection probe, in $d_{8}$-THF with tetramethylsilane (TMS) as an internal standard. ${ }^{31} \mathrm{P}-\mathrm{NMR}$ spectra of samples were recorded on a Bruker Avance III $400 \mathrm{MHz}$ spectrometer, with a $5 \mathrm{~mm}$ TIX triple resonance detection probe, in $d_{8}$-THF with diethylphosphite (DEP) as an internal 
standard. The chromatographic parameters of the samples were determined using a size exclusion chromatography set-up from Viscotek (Viscotek TDAmax) equipped with a differential viscometer (DV) and right-angle laser-light scattering (RALLS, Viscotek), low-angle laser-light scattering (LALLS, Viscotek) and refractive index (RI) detectors. The column set consisted of a PL $10 \mathrm{~mm}$ guard column $\left(50 \times 7.5 \mathrm{~mm}^{2}\right)$ followed by one Viscotek T200 column (6 $\mu \mathrm{m})$, one MIXED-E PLgel column $(3 \mu \mathrm{m})$ and one MIXED-C PLgel column $(5 \mu \mathrm{m})$. A dual piston pump was set with a flow rate of $1 \mathrm{~mL} / \mathrm{min}$. The eluent (THF) was previously filtered through a $0.2 \mu \mathrm{m}$ filter. The system was also equipped with an on-line degasser. The tests were done at $30^{\circ} \mathrm{C}$ using an Elder CH-150 heater. Before the injection $(100 \mu \mathrm{L})$, the samples were filtered through a polytetrafluoroethylene (PTFE) membrane with $0.2 \mu \mathrm{m}$ pore. The system was calibrated with narrow PS standards. The $d \mathrm{n} / d \mathrm{c}$ value was determined as 0.105 for PVC. Molecular weight $\left(M_{\mathrm{n}}{ }^{\mathrm{SEC}}\right)$ and dispersity $\left(\bigoplus=M_{\mathrm{w}} / M_{\mathrm{n}}\right)$ of synthesized polymers were determined by triple detection calibration using the OmniSEC software version: 4.6.1.354.

\subsection{Procedures}

NMP of VC was carried out in a $50 \mathrm{~mL}$ glass high-pressure tube equipped with a magnetic stir bar. In the kinetic studies each point represents a single experiment.

\section{Typical procedure for the NMP of VC in DCM at $42^{\circ} \mathrm{C}$ with $[\mathrm{VC}]_{0} /[\mathrm{MAMA}-\mathrm{SG} 1]_{0}=$ 250/1}

A 50-mL Ace Glass $8645 \# 15$ pressure tube, equipped with a bushing and a plunger valve, was charged with a mixture of BlocBuilder alkoxyamine (111 mg, $0.29 \mathrm{mmol})$ and DCM $(5.0 \mathrm{~mL})$ (previously bubbled with nitrogen for $5 \mathrm{~min})$. The precondensed VC $(5 \mathrm{~mL}, 73$ mmol) was added to the tube. The exact amount of VC was determined gravimetrically. The tube was sealed, submerged in liquid nitrogen and degassed through the plunger valve by applying reduced pressure and filling the tube with nitrogen about 20 times. The valve was closed and the tube reactor was placed in a water bath at $42{ }^{\circ} \mathrm{C} \pm 0.5^{\circ} \mathrm{C}$ under stirring $(700 \mathrm{rpm})$. After $24 \mathrm{~h}$, the reaction was stopped by plunging the tube into ice water. The tube was slowly opened, the excess VC was distilled, and the mixture was precipitated into $250 \mathrm{~mL}$ of methanol. The polymer was separated by filtration and dried in a vacuum oven until constant weight, yielding $2.58 \mathrm{~g}(56.6 \%)$ of PVC $\left(M_{\mathrm{n}}^{\mathrm{SEC}}=10800\right.$, $Ð=1.49)$. 


\section{Typical procedure for the "one-pot" chain extension experiment from SG1- terminated PVC}

A 50-mL Ace Glass $8645 \# 15$ pressure tube, equipped with a bushing and a plunger valve, was charged with a mixture of BlocBuilder alkoxyamine (167 mg; $0.44 \mathrm{mmol}$ ) and DCM $(3.0 \mathrm{~mL})$ (previously bubbled with nitrogen for $5 \mathrm{~min})$. The precondensed VC $(3.0 \mathrm{~mL}$, $43.7 \mathrm{mmol}$ ) was added to the tube. The exact amount of $\mathrm{VC}$ was determined gravimetrically. The tube was sealed, submerged in liquid nitrogen and degassed through the plunger valve by applying reduced pressure and filling the tube with nitrogen about 20 times. The valve was closed, and the tube reactor was placed in a water bath at $42{ }^{\circ} \mathrm{C}$ under stirring (700 rpm). After $7 \mathrm{~h}$, the reaction was stopped by plunging the tube into ice water. The tube was slowly opened and the excess VC was evaporated inside a fume hood. The monomer conversion (conv.) were determined gravimetrically (49.1\%), and the $M_{\mathrm{n}} \mathrm{SEC}=6000$ and $Ð=1.60$ were determined by SEC. DCM $(14.0 \mathrm{~mL})$ (previously bubbled with nitrogen for $5 \mathrm{~min})$ and the precondensed VC (14.0 $\mathrm{mL}, 204 \mathrm{mmol})$ were added in the medium without any purification of the previously obtained PVC-SG1 macroinitiator. The tube was sealed, submerged in liquid nitrogen and degassed through the plunger valve by applying reduced pressure and filling the tube with nitrogen about 20 times. The valve was closed, and the tube reactor was placed in a water bath at $42{ }^{\circ} \mathrm{C}$ under stirring $(700 \mathrm{rpm})$. The reaction was stopped after $48 \mathrm{~h}$ by plunging the tube into ice water. The tube was slowly opened and the excess VC was distilled. The monomer conversion were determined gravimetrically $(44.1 \%)$, and the $M_{\mathrm{n}} \mathrm{SEC}=20600$ and $Ð=$ 1.59 of the resulting PVC- $b$-PVC diblock copolymer were determined by SEC.

\section{Typical procedure for the synthesis of PVC-b-PMMA diblock copolymer by NMP}

The PVC-SG1 macroinitiator $\left(\operatorname{conv}=66 \%, M_{\mathrm{n}}{ }^{\text {th }}=5000, M_{\mathrm{n}}{ }^{\mathrm{SEC}}=6600, Ð=1.56\right)$ was obtained following the previously described procedure. After precipitation in methanol, the polymer was dissolved in THF and reprecipitated in methanol. The polymer was dried under vacuum until constant weight. A mixture of MMA (5.0 mL, $46.9 \mathrm{mmol})$ and PVC-SG1 macroinitiator $\left(M_{\mathrm{n}}^{\mathrm{SEC}}=6600, \oslash=1.56,310 \mathrm{mg}, 0.047\right.$ $\mathrm{mmol})$, previously dissolved in DMSO $(5.0 \mathrm{~mL})$, was added to the Schlenk reactor. The reactor was deoxygenated by five freeze-pump-thaw cycles and filled with nitrogen. Then the reactor was placed in the oil bath at $100{ }^{\circ} \mathrm{C}$ under stirring $(600$ $\mathrm{rpm})$. The reaction was stopped after $54 \mathrm{~h}$ and the mixture was analyzed by ${ }^{1} \mathrm{H}$ NMR 
spectroscopy to determine the MMA conversion (45.5\%) and by SEC to determine the the macromolecular characteristics of the resulting PVC- $b$-PMMA diblock copolymer $\left(M_{\mathrm{n}}^{\mathrm{SEC}}=44700\right.$ and $\left.Ð=1.89\right)$.

\section{Typical procedure for the synthesis of PVC-b-P(MMA-co-S) copolymer by NMP}

The PVC-SG1 macroinitiator $\left(\operatorname{conv}=66 \%, M_{\mathrm{n}}{ }^{\text {th }}=5000, M_{\mathrm{n}}{ }^{\mathrm{SEC}}=6600, Ð=1.56\right)$ was obtained following the previously described procedure. After precipitation in methanol, the polymer was dissolved in THF and reprecipitated in methanol. The polymer was dried under vacuum until constant weight. A mixture of MMA (5.0 mL, $46.9 \mathrm{mmol}), \mathrm{S}(0.52 \mathrm{~mL}, 4.5 \mathrm{mmol})$ and PVC-SG1 macroinitiator $\left(M_{\mathrm{n}} \mathrm{SEC}=6000, Ð\right.$ $=1.60,451 \mathrm{mg}, 0.075 \mathrm{mmol})$, previously dissolved in DMF $(5.52 \mathrm{~mL})$, was added to the Schlenk reactor. The reactor was deoxygenated by five freeze-pump-thaw cycles and filled with nitrogen. Then the reactor was placed in the oil bath at $100{ }^{\circ} \mathrm{C}$ under stirring $(600 \mathrm{rpm})$. The reaction was stopped after $44 \mathrm{~h}$ and the mixture was analyzed by ${ }^{1} \mathrm{H}$ NMR spectroscopy to determine the MMA (34.5\%) and S (36.8 \%) and by SEC to determine the the macromolecular characteristics of the resulting PVC- $b$-P(MMAco-S $)$ copolymer $\left(M_{\mathrm{n}}^{\mathrm{SEC}}=36400\right.$ and $\left.Ð=1.78\right)$.

\subsection{Computational Procedures}

In this work we used the high-level composite ab initio G3(MP2)-RAD method ${ }^{23}$ in conjunction with an ONIOM inspired approximation and M06-2X thermochemistry ${ }^{24}$ to obtain accurate gas-phase energies. The SMD continuum solvation method ${ }^{25}$ was used to model implicit solvent effects, with dichloromethane, toluene and methyl propanoate used as solvents for the vinyl chloride, styrene and methyl methacrylate systems, respectively. Similar methodology has been previously shown to predict accurate values for the thermodynamics (and kinetics) of a wide range of radical reactions, including alkoxyamine bond disassociation energies. ${ }^{26}$ All standard ab initio molecular orbital theory and density functional theory calculations were performed using Gaussian $09^{27}$ and Molpro $2012^{28}$ software packages. A more detailed description of all the computational procedures can be found in the supporting information.

\section{Results and discussion}




\subsection{Influence of the solvent}

In this work, the controlling ability of the BlocBuilder alkoxyamine was investigated for the polymerization of $\mathrm{VC}$. Using an alkoxyamine avoids the use of an additional conventional radical initiator since both an initiating radical and a nitroxide are released at elevated temperature. Additionally, this alkoxyamine exhibits a high dissociation rate constant $\left(k_{\mathrm{d}}=0.34 \mathrm{~s}^{-1} \text { at } 120{ }^{\circ} \mathrm{C}\right)^{29}$ thus enabling NMP to proceed at low temperature, unlike many other alkoxyamines.

The first study was focused on the influence of the solvent over the polymerization. Different solvents and solvent mixtures were selected based on the solubility of PVC and further investigated for the NMP of VC initiated by BlocBuilder alkoxyamine at $42{ }^{\circ} \mathrm{C}$ (Table 1). Results showed that the BlocBuilder alkoxyamine was able to significantly improve the NMP of VC compared to early attempts by producing PVC with dispersities far below 2. This was effective in a wide range of solvents which demonstrates the versatility of the NMP system used. In particular, best results were obtained in cyclohexanone (Table 1, entry 4), DMSO (Table 1, entries 5 and 6) and especially in DCM for which $Ð=1.49$ (Table 1, entry 8). In an attempt to accelerate the VC

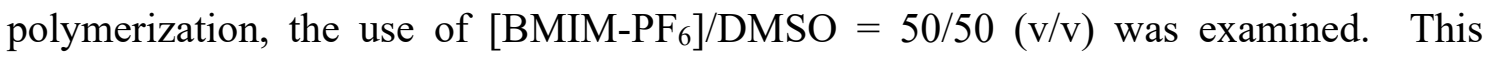
confirmed the synergetic effect observed in SARA ATRP, since the final conversion (conv.) was much higher than in pure DMSO. ${ }^{30} \mathrm{THF}, \mathrm{DMF}$ and sulfolane/DMSO $=80 / 20$ $(\mathrm{v} / \mathrm{v})(20 \%$ of DMSO was added to the sulfolane to allow the solubilization of BlocBuilder in the mixture) appeared less adequate solvents since $Ð$ values ranged from 1.72 to 1.78 (Table 1, entries $1-3$ ). Nevertheless, there was in all cases a good agreement between the theoretical and experimental molecular weights, which suggested good control over the PVC structure. The addition of $10 \%$ of free SG1 (Table 1, entry 9) significantly reduced the final conversion but had no beneficial effect on the $\oslash$.

Table 1. Conversion and Macromolecular Characteristics Obtained for the NMP of VC Using Different Solvents at $42{ }^{\circ} \mathrm{C}$ After $24 \mathrm{~h}$.

\begin{tabular}{cccccc}
\hline Entry $^{a}$ & Solvent & Conv. (\%) & $\begin{array}{c}\boldsymbol{M}_{\mathbf{n}}^{\text {th }} \times \mathbf{~ 1 0}^{-3} \\
(\mathbf{g} / \mathbf{m o l})\end{array}$ & $\begin{array}{c}\boldsymbol{M}_{\mathbf{n}}^{\text {SEC }} \times \mathbf{~ 1 0}^{-3} \\
(\mathbf{g} / \mathbf{m o l})\end{array}$ & $\boldsymbol{\nexists}$ \\
\hline 1 & THF & 30 & 5.5 & 5.9 & 1.72 \\
2 & DMF & 22 & 5.3 & 5.9 & 1.73 \\
3 & Sulfolane/DMSO $=80 / 20(\mathrm{v} / \mathrm{v})$ & 29 & 5.8 & 6.1 & 1.78
\end{tabular}




\begin{tabular}{cccccc}
4 & Cyclohexanone & 39 & 7.4 & 7.7 & 1.59 \\
5 & DMSO & 14 & 3.5 & 3.8 & 1.47 \\
$6^{b}$ & DMSO & 22 & 5.3 & 5.8 & 1.58 \\
7 & BMIM-PF $_{6} / \mathrm{DMSO}=50 / 50(\mathrm{v} / \mathrm{v})$ & 32 & 7.0 & 8.8 & 1.59 \\
8 & $\mathrm{DCM}$ & 57 & 10.7 & 10.8 & 1.49 \\
$9^{c}$ & $\mathrm{DCM}$ & 29 & 5.3 & 9.7 & 1.56 \\
\hline
\end{tabular}

${ }^{a}$ Reaction conditions: $[\mathrm{VC}]_{0} /[\mathrm{BlocBuilder}]_{0}=250 ;[\mathrm{VC}]_{0} /[$ solvent $]=1 / 1(\mathrm{v} / \mathrm{v}) .{ }^{b}$ Polymerization time $\left(\mathrm{t}_{\mathrm{rx}}\right)=$ $48 \mathrm{~h} .{ }^{c}$ Using additional SG1 free: $[\mathrm{SG} 1]_{0} /[\mathrm{BlocBuilder}]_{0}=0.1$.

Based on these results, DCM was chosen as the optimal solvent for a comprehensive kinetic study of the NMP of VC. After about $30 \mathrm{~h}$, a rather high VC conversion was obtained ( $\sim 60 \%)$. This resulted in a first-order kinetics (Figure 1a), suggesting a constant concentration of growing radicals during the polymerization. This is in sharp contrast to the two linear dependencies of $\ln [\mathrm{M}]_{0} /[\mathrm{M}]$ vs. time plots which were observed in the polymerization of VC by both SET-DTLRP ${ }^{16 i-k}$ and RAFT, ${ }^{10}$ but is in accordance with the SARA-ATRP method. ${ }^{8 a}$ Additionally, the SG1-mediated NMP of VC initiated by the BlocBuilder alkoxyamine in DCM enabled higher final monomer conversion $(60 \%)$ to be reached than that obtained with the RAFT system (50\%) previously reported. ${ }^{10} \mathrm{NMP}$ of VC was also rather well-controlled as shown by the decrease of the $\oslash$ values during the reaction, as well as by the good agreement between experimental and theoretical molecular weight values (Figure 1 (b)). Finally, SEC chromatograms of PVC samples obtained at different times of reaction showed unimodal distributions with no visible sign of accumulation of dead polymer chains and significant shifts towards higher molecular weights (Figure 1 (c)).

(a)

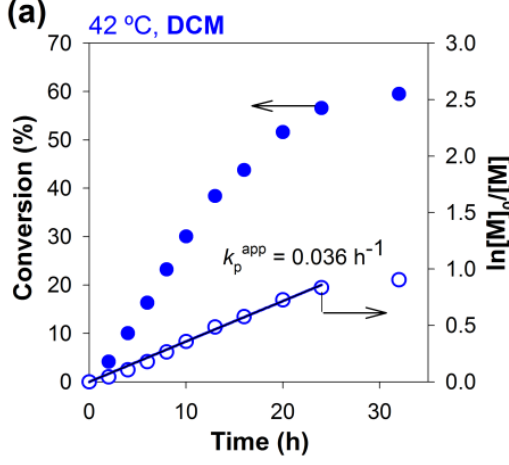

(b)

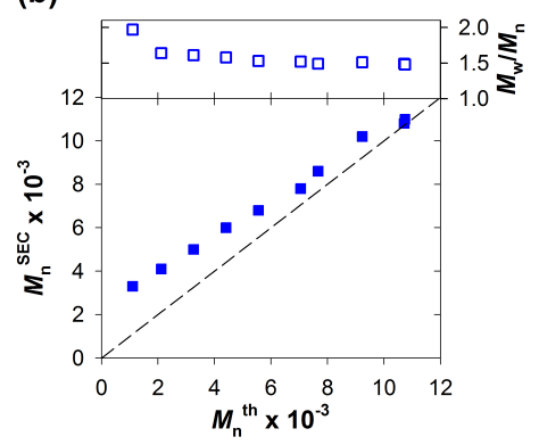

(c)

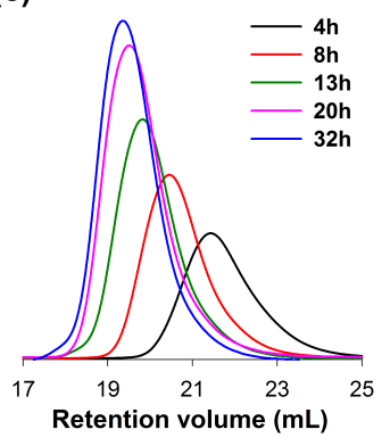

Figure 1. NMP of VC in DCM at $42{ }^{\circ} \mathrm{C}$ initiated by the SG1-based BlocBuilder alkoxyamine. (a) Conversion and $\ln [\mathrm{M}]_{0} /[\mathrm{M}]$ vs. time. (b) Number-average molecular 
weight $\left(M_{\mathrm{n}}{ }^{\mathrm{SEC}}\right)$ and dispersity $\left(M_{\mathrm{w}} / M_{\mathrm{n}}\right) v s$. theoretical number-average molecular weight $\left(M_{\mathrm{n}}^{\text {th }}\right)$. (c) Evolution of the SEC traces during the polymerization. Reaction conditions: $[\mathrm{VC}]_{0} /[\mathrm{BlocBuilder}]_{0}=250 / 1 ;[\mathrm{VC}]_{0} /[$ solvent $]=1 / 1(\mathrm{v} / \mathrm{v})$.

\subsection{Influence of the monomer concentration}

In solution NMP, the initial concentration of monomer (which also corresponds to the monomer-to-solvent ratio) may strongly influence the polymerization rate and may also sometimes impact the quality of control. ${ }^{7 \mathrm{~d}, 31}$ Three different monomer-to-solvent ratios $(1 / 2,1 / 1$ and $2 / 1)$ were investigated for the NMP of VC in DCM at $42{ }^{\circ} \mathrm{C}$ initiated by the BlocBuilder alkoxyamine (Table 2, entries 1-3). Overall, the results showed no general trend regarding the influence of the initial concentration of VC. As expected, the rate of reaction increased with the initial concentration of $\mathrm{VC}$ (Table 2, entries 1-2), as higher monomer conversion was achieved for the same reaction time (i.e., 24 h). However, for the highest monomer concentration studied (i.e., $[\mathrm{VC}]_{0} /[\mathrm{DCM}]=2 / 1$ ) there was an apparent decrease on the rate of polymerization, as judged by the lower monomer conversion obtained for the more diluted reaction medium (Table 2, entries 2-3). This might be related to the poor solubility of the VC in the growing PVC, which can cause diffusional problems during the polymerization and limit monomer conversion.

Table 2. Conversion and Macromolecular Characteristics Obtained for the NMP of VC in DCM at $42{ }^{\circ} \mathrm{C}$ After $24 \mathrm{~h}$.

\begin{tabular}{cccccc}
\hline Entry $^{a}$ & {$[\mathbf{V C}]_{0} /[\mathbf{D C M}](\mathbf{v} / \mathbf{v})$} & Conv. $(\%)$ & $\begin{array}{c}\boldsymbol{M}_{\mathbf{n}}^{\text {th }} \mathbf{x} \mathbf{1 0}^{-3} \\
(\mathbf{g} / \mathbf{m o l})\end{array}$ & $\begin{array}{c}\boldsymbol{M}_{\mathbf{n}} \mathbf{S E C}_{\mathbf{m}} \mathbf{~ 1 0}^{-3} \\
(\mathbf{g} / \mathbf{m o l})\end{array}$ & $\boldsymbol{\oplus}$ \\
\hline 1 & $1 / 2$ & 39 & 7.6 & 8.5 & 1.58 \\
2 & $1 / 1$ & 57 & 10.7 & 10.8 & 1.49 \\
3 & $2 / 1$ & 45 & 7.8 & 11.4 & 1.56 \\
\hline
\end{tabular}

${ }^{a}$ Reaction Conditions: $[\mathrm{VC}]_{0} /[\mathrm{BlocBuilder}]_{0}=250 / 1$.

\subsection{Influence of polymerization temperature}

The polymerization temperature is an important parameter to consider when optimizing RDRP systems. Temperature is particularly crucial for standard NMP, as the activation/deactivationequilibrium of the initiating and propagating species are solely governed by temperature. Also, in the case of PVC, high temperatures can contribute to the appearance of structural defects in the polymeric structure. ${ }^{14,16 \mathrm{~g}} \mathrm{NMP}$ of VC was 
evaluated in the range of $30-60^{\circ} \mathrm{C}$ (Table 3). The results showed that NMP of VC can proceed successfully at near room temperature $\left(\mathrm{T}=30^{\circ} \mathrm{C}\right)$ with no detrimental effect on the control of PVC compared to the same experiment performed at $42{ }^{\circ} \mathrm{C}(\nexists \approx 1.50$, Table 3 , entries 1-2). However, when the temperature was increased up to $60^{\circ} \mathrm{C}$ (Table 3 , entry 3 ), a significant increase of the $Ð$ was noticed, suggesting the occurrence of side and/or irreversible termination reactions during the polymerization. This loss of control was also accompanied by a decrease in the final monomer conversion, for the same reaction time. Considering both the control over the molecular weight and the polymerization rate, a temperature of $42{ }^{\circ} \mathrm{C}$ appears to be optimal.

Table 3. Conversion and Macromolecular Characteristics Obtained for the NMP of VC in DCM at Different Temperatures After $24 \mathrm{~h}$.

\begin{tabular}{|c|c|c|c|c|c|}
\hline Entry $^{a}$ & $\mathbf{T}\left({ }^{\circ} \mathbf{C}\right)$ & Conv. (\%) & $\begin{array}{c}M_{\mathrm{n}}^{\text {th }} \times 10^{-3} \\
(\mathrm{~g} / \mathrm{mol}) \\
\end{array}$ & $\begin{array}{c}M_{\mathrm{n}}^{\mathrm{SEC}} \mathbf{X} 10^{-3} \\
(\mathrm{~g} / \mathrm{mol})\end{array}$ & $\boldsymbol{\oplus}$ \\
\hline 1 & 30 & 39.7 & 7.1 & 7.7 & 1.53 \\
\hline 2 & 42 & 56.6 & 10.7 & 10.8 & 1.49 \\
\hline 3 & 60 & 37.1 & 6.7 & 6.1 & 1.68 \\
\hline
\end{tabular}

${ }^{a}$ Reaction Conditions: $[\mathrm{VC}]_{0} /[\mathrm{BlocBuilder}]_{0}=250 / 1$.

\subsection{Influence of the degree of polymerization}

The robustness of a RDRP system can be evaluated by different criteria among which it is its ability to control the growth of polymer chains for different targeted molecular weights. Figure 2 shows the kinetics of the NMP of VC for a targeted number-average degree of polymerization $\left(D P_{\mathrm{n}}\right)$ of 100 . The polymerization proceeded in a controlled manner, with a good agreement between the experimental and predicted values (and $M_{\mathrm{n}} \mathrm{SEC}$ increased linearly with VC conversion, Figure S1), as well as decreasing $\oslash$ values throughout the reaction reaching $\sim 1.5$ (Figure $2 b$ ).As with the earlier experiments performed with $D P_{\mathrm{n}}=250$ (Figure 1), the SEC chromatograms of PVC samples obtained at different times intervals showed unimodal distributions with no visible sign of accumulation of dead polymer chains and constant shifts towards higher molecular weights (Figure 2c). 


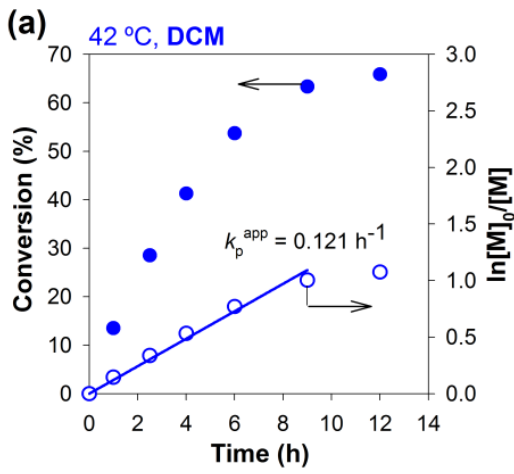

(b)

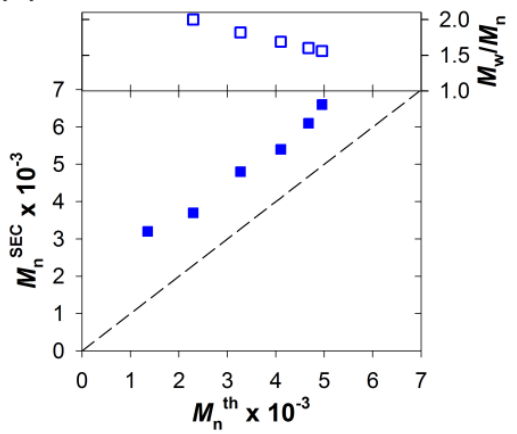

(c)

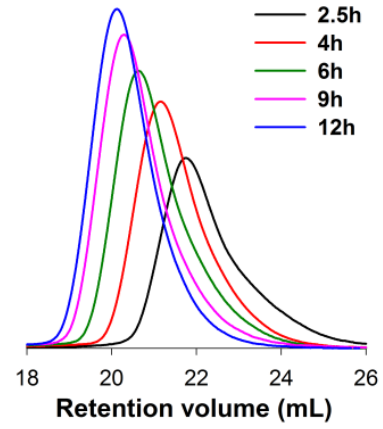

Figure 2. NMP of $\mathrm{VC}$ in $\mathrm{DCM}$ at $42{ }^{\circ} \mathrm{C}$ initiated by the SG1-based BlocBuilder alkoxyamine. (a) Conversion and $\ln [\mathrm{M}]_{0} /[\mathrm{M}] v s$. time. (b) $M_{\mathrm{n}}{ }^{\mathrm{SEC}}$ and $M_{\mathrm{w}} / M_{\mathrm{n}} v s \cdot M_{\mathrm{n}}{ }^{\text {th }}$. (c) Evolution of the SEC traces during the polymerization. Reaction conditions: $[\mathrm{VC}]_{0} /[\mathrm{BlocBuilder}]_{0}=100 / 1 ;[\mathrm{VC}]_{0} /[$ solvent $]=1 / 1(\mathrm{v} / \mathrm{v})$.

Additional studies were performed targeting different $D P_{\mathrm{n}}$ values of VC. The results presented on Table 4 demonstrate that it is possible to prepare well-defined PVC with a range of molecular weights, suggesting that the NMP of VC using BlocBuilder alkoxyamine is quite robust.

Table 4. Conversion and Macromolecular Characteristics Obtained for the NMP of VC in DCM at $42{ }^{\circ} \mathrm{C}$ for Different Targeted $D P_{\mathrm{n}}$ values ([VC] $\left.]_{0} /[\mathrm{BlocBuilder}]_{0}\right)$.

\begin{tabular}{|c|c|c|c|c|c|c|}
\hline Entry & {$[\mathrm{VC}]_{0} /[\mathrm{BlocBuilder}]_{0}$} & Time (h) & Conv. $(\%)$ & $\begin{array}{c}M_{\mathrm{n}}^{\text {th }} \times 10^{-3} \\
(\mathrm{~g} / \mathrm{mol})\end{array}$ & $\begin{array}{c}M_{\mathrm{n}}^{\mathrm{SEC}} \times 10^{-3} \\
(\mathrm{~g} / \mathrm{mol})\end{array}$ & $\boldsymbol{\oplus}$ \\
\hline 1 & $100 / 1$ & 7 & 49 & 4.3 & 6.0 & 1.60 \\
\hline 2 & $100 / 1$ & 12 & 66 & 5.0 & 6.6 & 1.56 \\
\hline 3 & $250 / 1$ & 24 & 57 & 10.7 & 10.8 & 1.49 \\
\hline 4 & $500 / 1$ & 24 & 47 & 15.9 & 16.9 & 1.54 \\
\hline 5 & $1000 / 1$ & 48 & 52 & 34.7 & 30.4 & 1.53 \\
\hline
\end{tabular}

\subsection{Analysis of the PVC structure}

To gain a deeper insight into the structure of the PVC obtained by SG1-mediated NMP initiated by the BlocBuilder alkoxyamine, a sample (Table 4, entry 1) was analyzed by ${ }^{1} \mathrm{H}$ NMR spectroscopy (Figure 3). The characteristics signals of the PVC assigned on the spectrum were in agreement with those reported in the literature. ${ }^{7 a, 8 a, 10}$ The ${ }^{1} \mathrm{H}$ NMR spectrum of the BlocBuilder alkoxyamine, also included in Figure 3, to confirm ${ }^{9}$ the 
retention of both chain-end functionalities on the polymer. The spectrum of the PVC reveals the resonances of the repeat unit $\mathrm{CH}_{2}-\mathrm{CHCl}: \mathbf{g}(1.9-2.7 \mathrm{ppm})$ and $\mathbf{h}(4.2-4.7 \mathrm{ppm})$, respectively. The spectrum of the $\mathrm{PVC}$ also reveals the resonances of the initating and mediating BlocBuilder alkoxyamine fragments: $\mathbf{a}$ at 1.62-1.64 ppm, b, $\mathbf{c}$ and $\mathbf{f}$ at 1.10$1.40 \mathrm{ppm}, \mathbf{d}$ at $3.35-3.42 \mathrm{ppm}$ and e at 3.98-4.15 ppm.

To evaluate the impact of the BlocBuilder alkoxyamine on the formation of structural defects of the PVC obtained by SG1-mediated NMP (Table 4, entry 1), it was synthesized a PVC $\left(M_{\mathrm{n}}^{\mathrm{SEC}}=29.3 \times 10^{3} ; Ð=1.76\right)$ by FRP (Trigonox $187 \mathrm{~W} 40$ was used as conventional initiator) at the same temperature $\left(42^{\circ} \mathrm{C}\right)$ and using the same solvent (DCM) that it was used to synthesize this PVC. The most representative structural defects for transfer to monomer and easily detected is the $-\mathrm{CH}=\mathrm{CH}-\mathrm{CH}_{2} \mathrm{Cl}$. Comparing the signal intensities of hydrogen atoms of PVC PVC backbone $-\mathrm{CH}_{2} \mathrm{CHCl}-(\mathbf{h}, 4.2-4.7 \mathrm{ppm})$ and the hydrogen atoms of the $-\mathrm{CH}=\mathrm{CH}-\mathrm{CH}_{2} \mathrm{Cl}$ defect structure $(5.8 \mathrm{ppm}$ for $\mathrm{CH}=\mathrm{CH}$ (s1, Figure 3 and Figure S2)) allows quantifying the defect in PVC samples (it is not possible to do the comparison considering the $4.1 \mathrm{ppm}$ for $\mathrm{CH}_{2}$ (s2, Figure 3 and Figure S2) because this signal is overlapped with e in the PVC-SG1). The $-\mathrm{CH}_{2} \mathrm{CHCl}-/-\mathrm{CH}=\mathrm{CH}-$ $\mathrm{CH}_{2} \mathrm{Cl}$ molar ratio is $1000 / 0.86$ for PVC-FRP while this ratio is $1000 / 0.42$ for PVC-SG1. These results showed much less structural defects in the PVC obtained by SG1-mediated NMP, which is also in agreementwith other RDRP techniques as SET-DTLRP ${ }^{14}$ and RAFT. ${ }^{10}$ 


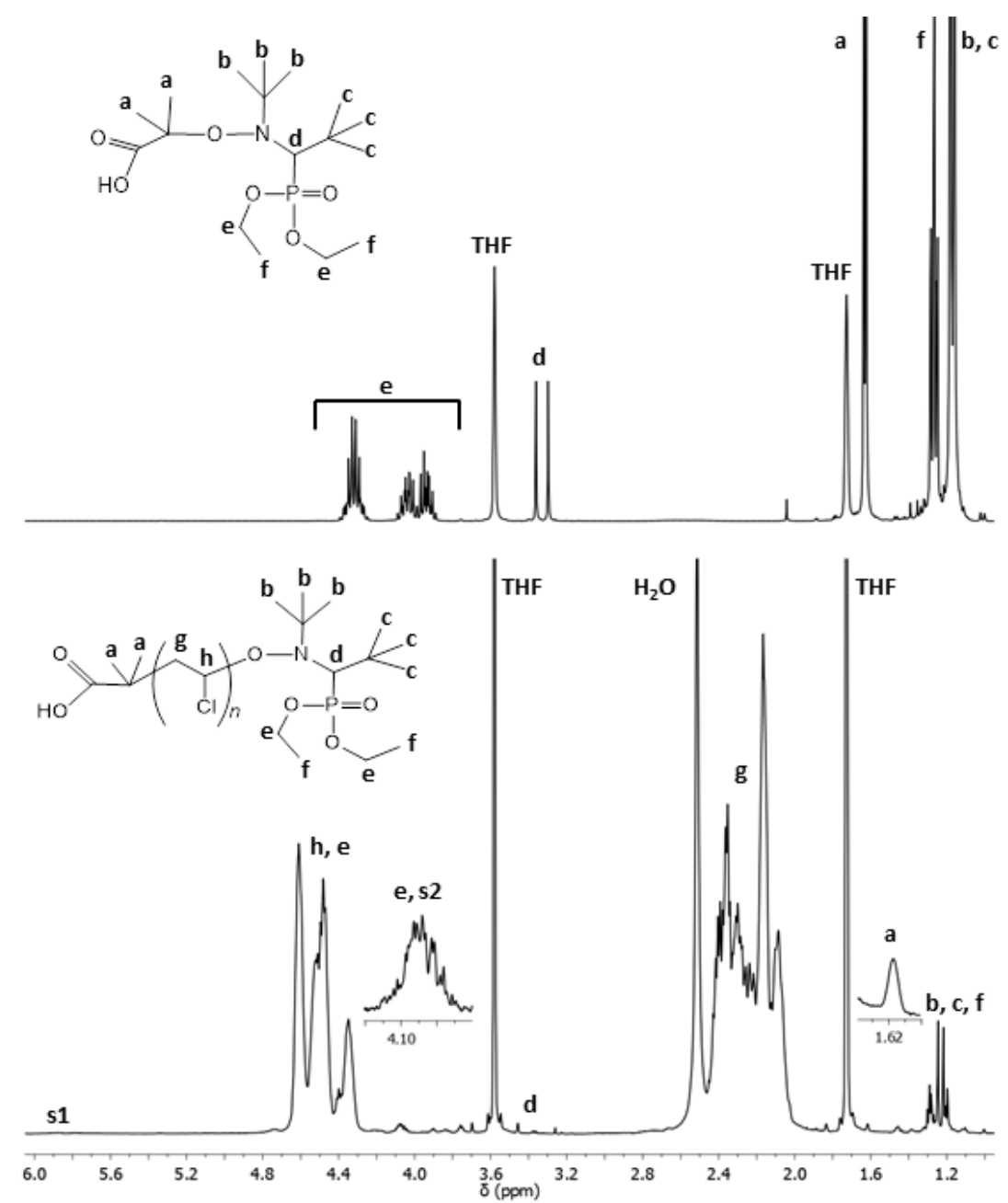

Figure 3. ${ }^{1} \mathrm{H}$ NMR spectra in $d_{8}$-THF of (a) the BlocBuilder alkoxyamine and (b) the purified PVC $\left(M_{\mathrm{n}}^{\mathrm{SEC}}=6000 ; Ð=1.60\right)$ obtained in Table 4 , entry 1 .

To probe the end-group fidelity of the synthesized PVC, ${ }^{31} \mathrm{P}$ NMR spectroscopy was performed. This is a convenient and accurate method, which relies on the determination of the living chain fraction (LF) by quantifying the presence of the phosphorus-containing SG1 nitroxide end-group with diethyl phosphite (DEP) as an internal reference. ${ }^{12,32}$ The spectrum of PVC-SG1 is reported in Figure 4 and gave a LF of $\sim 91 \%$, which is similar to LF values reported for the NMP of styrenics and acrylates, and clearly establishes the living nature of the PVC and retention of the SG1 fragment. This also opens the door to chain extensions to prepare PVC-based block copolymers by NMP. 


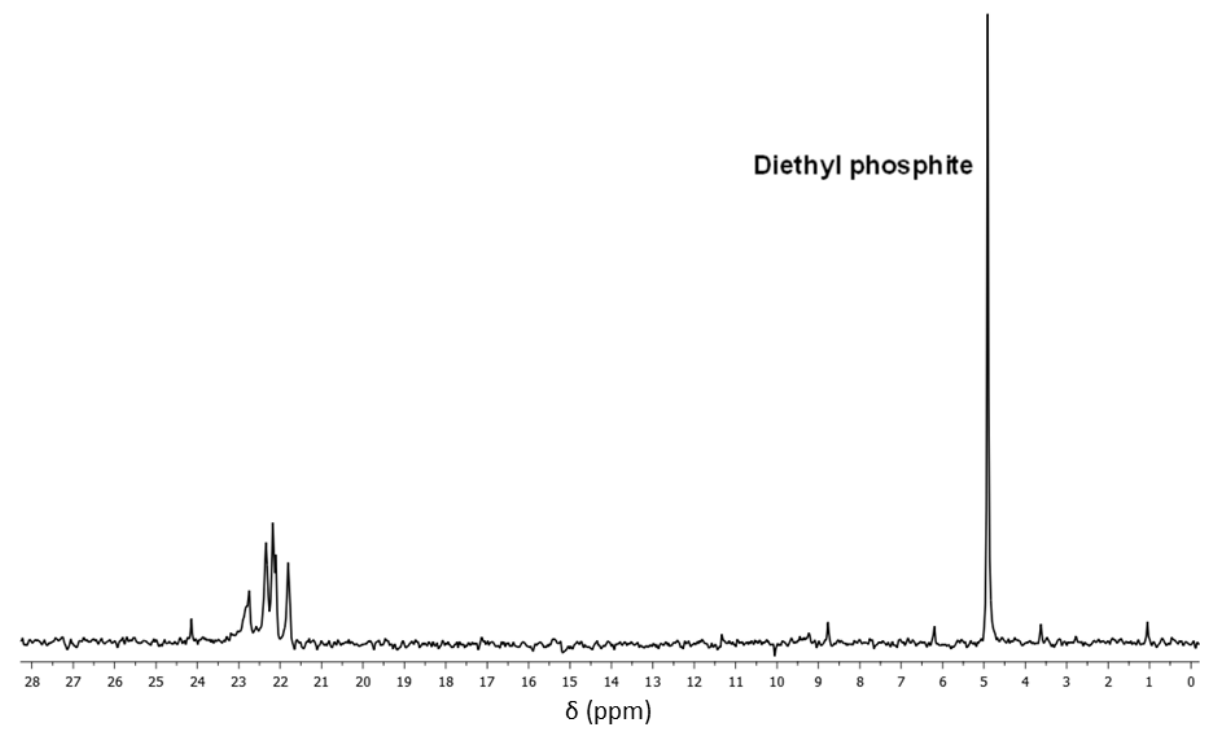

Figure 4. ${ }^{31} \mathrm{P}$ NMR spectra in $d_{8}$-THF of the purified PVC $\left(M_{\mathrm{n}} \mathrm{SEC}=6000 ; Ð=1.60\right)$ obtained in Table 4 , entry 1.

\subsection{Evaluation of the PVC livingness}

The livingness of a polymer obtained by a RDRP technique is of paramount importance for block copolymer synthesis and macromolecular engineering purposes. The living character of the previously-obtained PVC-SG1 (Table 4, entry 1) was further confirmed by a successful chain extension experiment by a "one-pot" chain extension experiment from SG1-terminated PVC of VC in DCM at $42{ }^{\circ} \mathrm{C}$. The SEC traces presented in Figure 5 showed a complete shift of the low molecular weight SG1-terminated PVC macroinitiator $\left(\mathrm{conv}=49 \%, M_{\mathrm{n}}^{\text {th }}=4300, M_{\mathrm{n}}{ }^{\mathrm{SEC}}=6000, D=1.60\right)$ towards high molecular weight polymer $\left(\mathrm{conv} .=44 \%, M_{\mathrm{n}}^{\text {th }}=26500, M_{\mathrm{n}}{ }^{\mathrm{SEC}}=20600, \oslash=1.59\right.$ ), thus demonstrating the formation of an extended PVC- $b$-PVC. 


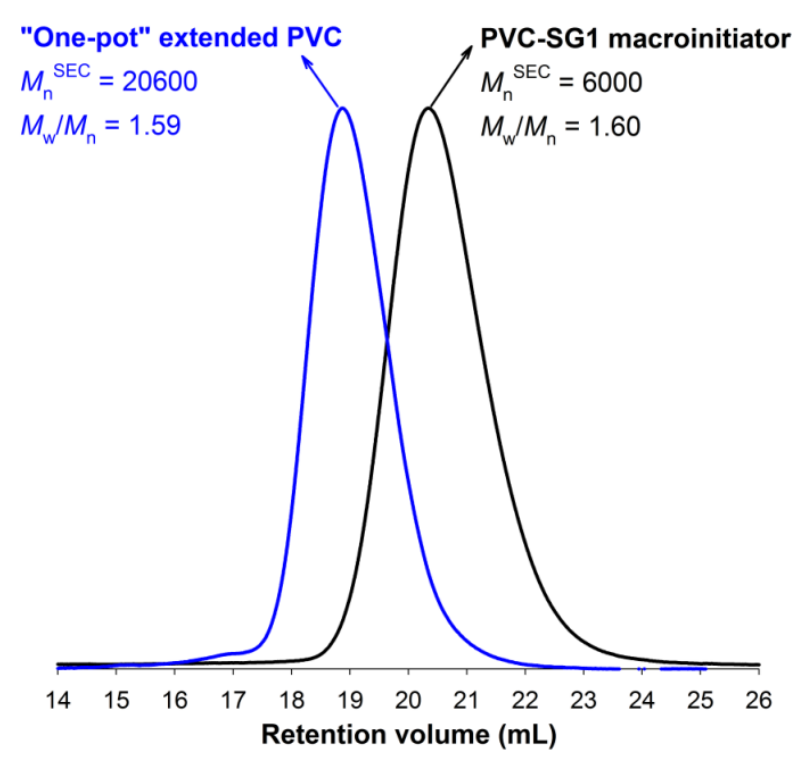

Figure 5. SEC chromatograms of the PVC-SG1 macroinitiator (conv. $=49 \%, M_{\mathrm{n}}^{\text {th }}=$ $\left.4300, M_{\mathrm{n}} \mathrm{SEC}=6000, Ð=1.60\right)$ (black line), and the extended PVC- $b$-PVC (conv. $=44 \%$, $M_{\mathrm{n}}^{\text {th }}=26500, M_{\mathrm{n}}^{\mathrm{SEC}}=20600, Ð=1.59$ ) (blue line) after "one-pot" chain extension in DCM.

Additionally, to diversify the range of PVC-based macromolecular architectures, a PVCSG1 (Table 4, entry 2) macroinitiator $\left(M_{\mathrm{n}}^{\mathrm{SEC}}=6600, \emptyset=1.56\right)$ initiated the NMP of MMA to produce PVC- $b$-PMMA (conv. MMA $^{2}=45.5 \%, M_{\mathrm{n}}^{\text {th }}=52100, M_{\mathrm{n}}{ }^{\mathrm{SEC}}=44700, Ð$ $=1.89$ ) diblock copolymer and the NMP of MMA with $10 \%$ of S to produce PVC- $b$ $\mathrm{P}(\mathrm{MMA}-c o-\mathrm{S})\left(\mathrm{conv} \cdot \mathrm{MMA}=34.5 \%\right.$, conv.St $=36.8 \%,{M_{\mathrm{n}}}^{\text {th }}=44800, M_{\mathrm{n}}{ }^{\mathrm{SEC}}=36400, Ð=$ 1.78) diblock copolymer (Figure 6).

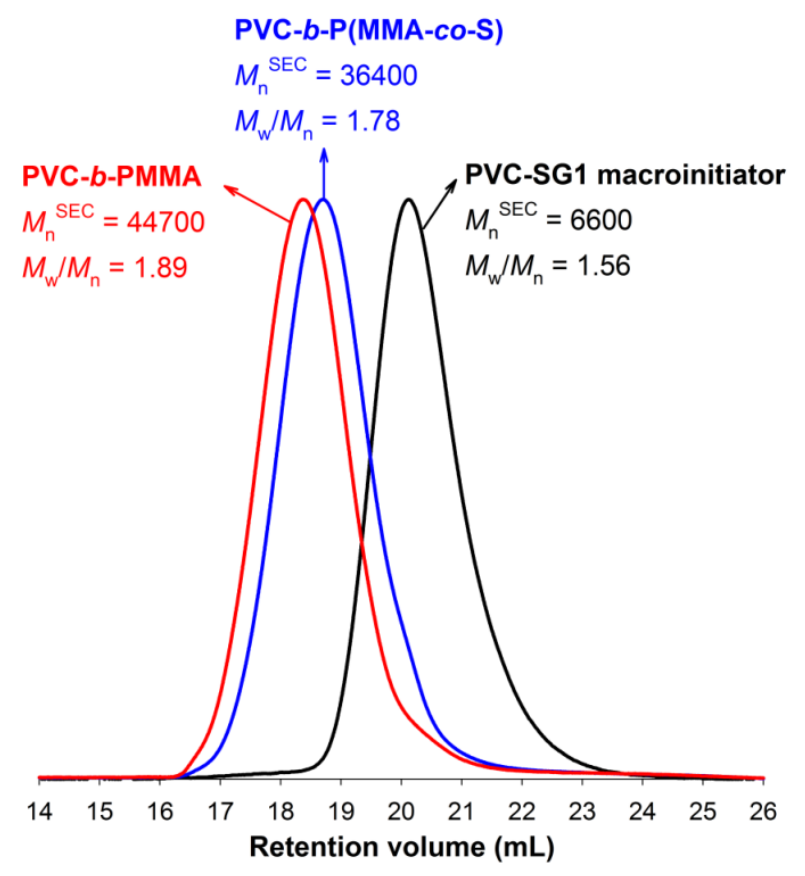


Figure 6. SEC chromatograms of the PVC-SG1 macroinitiator (conv. $=66 \%, M_{\mathrm{n}}^{\text {th }}=$ $5000, M_{\mathrm{n}}^{\mathrm{SEC}}=6600, Ð=1.56$ ) (black line), the PVC- $b$-PMMA diblock copolymer (conv.MMA $\left.=45.5 \%, M_{\mathrm{n}}^{\text {th }}=52100, M_{\mathrm{n}}^{\mathrm{SEC}}=44700, Ð=1.89\right)($ red line) by NMP in DMSO, and PVC- $b-\mathrm{P}(\mathrm{MMA}-c o-\mathrm{S})\left(\mathrm{conv} \cdot \mathrm{MMA}=34.5 \%\right.$, conv.s $=36.8 \%, M_{\mathrm{n}}^{\text {th }}=44800, M_{\mathrm{n}}{ }^{\mathrm{SEC}}=$ $36400, Ð=1.78$ ) (blue line) block copolymer by NMP in DMF at $100{ }^{\circ} \mathrm{C}$ for 54 and $44 \mathrm{~h}$, respectively.

The chemical structure of the block copolymers were confirmed by ${ }^{1} \mathrm{H}$ NMR spectroscopy (Figure S3 and S4). These results demonstratedthe "living" character of the PVC-SG1 macroinitiator and the possibility of using the reported system in the synthesis of unique and novel PVC-based copolymers with unprecedented properties.

\subsection{Computational Studies on the mechanism of low temperature NMP of VC.}

NMP is a reversible deactivation radical polymerization process that employs stable nitroxide radical as a mediating species. Achieving a NMP with 'living' characteristics relies on the presence of a thermally labile $\mathrm{C}-\mathrm{O}$ bond in the corresponding polymeric alkoxyamine, otherwise deactivation of the prorogating radicals will be irreversible. The strength of this bond is dependent on the structure of the nitroxide and polymeric radical from which the alkoxyamine is composed. For a given nitroxide, the bond dissociation free-energy (BDFE) of the $\mathrm{C}-\mathrm{O}$ bond depends on both the stability of the polymeric radical and its substitution; with more stable and more bulky substituted polymeric radicals affording lower BDFEs. ${ }^{22}$ For these reasons, one would intuitively expect that NMP polymerization of VC mediated by SG1 radicals would fail, especially at low temperatures $\left(42{ }^{\circ} \mathrm{C}\right)$, because deactivation of the propagating radical should be irreversible. While SG1 radicals have mediated the successful NMPs of various monomers including, $n$-butyl acrylate $(n \text {-BA })^{21 \mathrm{a}}$ and $\mathrm{S},{ }^{21 \mathrm{a}}$ these polymerizations must be performed at elevated temperatures $\left(90-120{ }^{\circ} \mathrm{C}\right)$ to maintain reasonable levels of alkoxyamine homolysis. Additionally, it should also be noted that the propagating radical species in these polymerizations are significantly more stable and sterically hindered than $\mathrm{VC}$ radicals (see radical stabilization energies (RSE) in Table 5). ${ }^{26 \mathrm{~d}}$ To properly quantify the governing activation-deactivation equilibrium constant $(K)$ of the PVC-SG1 system, high-level theory was used to calculate the BDFE of the $\mathrm{C}-\mathrm{O}$ bond in corresponding 
alkoxyamine (see Table 5). For comparative purposes, the BDFEs of the $\mathrm{C}-\mathrm{O}$ bonds in both PS-SG1 and PMMA-SG1 alkoxyamines were also calculated using the same computational methodology. As electron donating substituents can destabilize the $\mathrm{O}-\mathrm{N}$ bond of the nitroxide, ${ }^{26 \mathrm{c}} \mathrm{O}-\mathrm{N}$ breakage was also examined for $\mathrm{VC}$.

Table 5. Radical Stabilization Energies (RSE), Bond Dissociation Free-Energies (BDFE) and $K$ for SG1-Mediated NMP of VC, S and MMA.

\begin{tabular}{|c|c|c|c|c|c|}
\hline \multirow{2}{*}{$\begin{array}{l}\text { Monomer System } \\
\text { (Bond Homolysis) }\end{array}$} & \multirow{2}{*}{$\begin{array}{c}\text { RSE of unimeric } \\
\text { radical }^{\mathrm{a}}\end{array}$} & \multicolumn{2}{|c|}{$40^{\circ} \mathrm{C}$} & \multicolumn{2}{|c|}{$100^{\circ} \mathrm{C}$} \\
\hline & & $\mathbf{B D F E}^{\mathbf{a}}$ & $K$ & $\mathbf{B D F E}^{\mathbf{a}}$ & $\boldsymbol{K}$ \\
\hline $\mathrm{VC}(\mathrm{C}-\mathrm{ON})$ & 13.2 & 134.0 & $4.5 \times 10^{-23}$ & 121.5 & $9.7 \times 10^{-18}$ \\
\hline $\mathrm{VC}(\mathrm{CO}-\mathrm{N})$ & - & 140.0 & $4.4 \times 10^{-24}$ & 128.0 & $1.2 \times 10^{-18}$ \\
\hline $\mathrm{S}(\mathrm{C}-\mathrm{ON})$ & 54.8 & 95.6 & $1.1 \times 10^{-16}$ & 83.2 & $2.2 \times 10^{-12}$ \\
\hline $\operatorname{MMA}(\mathrm{C}-\mathrm{ON})$ & 41.1 & 65.1 & $1.4 \times 10^{-11}$ & 51.9 & $5.4 \times 10^{-8}$ \\
\hline
\end{tabular}

${ }^{a} \mathrm{RSE}$ and BDFE values given in $\mathrm{kJ} \mathrm{mol}^{-1}$. Dichloromethane, toluene and methyl propanoate were used as solvents for VC, S and MMA, respectively. The VC, S and MMA radicals were modeled as dimers. RSE values were taken from reference ${ }^{26 \mathrm{~d}}$.

At $40{ }^{\circ} \mathrm{C}$, the $\mathrm{C}-\mathrm{O}$ bond BDFE of the PVC-SG1alkoxyamine is calculated to be $134.0 \mathrm{~kJ}$ $\mathrm{mol}^{-1}$, while the corresponding $K$ value is $4.5 \times 10^{-23}$. Even assuming a very fast diffusion

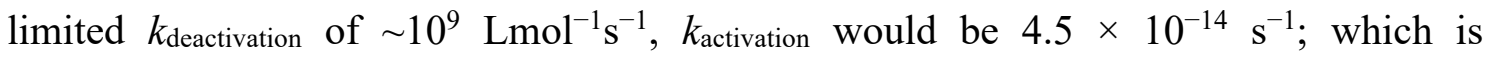
approximately 10 orders of magnitude too slow to mediate a successful NMP. In other words, the $\mathrm{C}-\mathrm{O}$ bond of the PVC-SG1 alkoxyamine is around $40-50 \mathrm{~kJ} \mathrm{~mol}^{-1}$ too strong to facilitate a viable NMP activation-deactivation equilibrium. Even at the elevated temperatures $\left(100^{\circ} \mathrm{C}\right)$ used for the MMA and MMA/S chain-extension experiments, $K$ is still over 5 orders of magnitude too low to facilitate sufficient levels of PVC-SG1 macroinitiator homolysis. Alternative O-N breakage of the PVC-SG1 alkoxyamine, which would decompose the SG1 nitroxide (irreversibly) into an aminyl radical, is also thermodynamically disfavored at both $40^{\circ} \mathrm{C}$ and $100{ }^{\circ} \mathrm{C}$.

In contrast, to the unfavorable $K$ value for the PVC-SG1 system, the $\mathrm{C}-\mathrm{O}$ bond of the PSSG1 alkoxyamine is predicted to be sufficiently labile at $100{ }^{\circ} \mathrm{C}$ (but not $40{ }^{\circ} \mathrm{C}$ ) to facilitate a successful NMP. This theoretical prediction is consistent with previous experimental results, as it is well known that the NMP of S must be performed at elevated temperatures (usually $\geq 90^{\circ} \mathrm{C}$ ) to yield polymeric products within practical time-frames. ${ }^{33}$ In contrast to the other two alkoxyamines, the $K$ value for the PMMA-SG1 system is 
predicted to be too large and so irreversible combination/disproportionation of propagating chains would severely compromise this NMP. ${ }^{34}$ Indeed, the addition of S monomer to MMA-SG1 polymerizations improves the livingness, as the intermediate styryl radicals are more susceptible deactivation by SG1 radicals. ${ }^{34}$ In summary, the theoretically predicted $K$ values are not only consistent with intuitive expectations based on a semi-quantitative analysis of the size and stability of the corresponding radical species, but also with previous experimental results in S-SG1 and MMA-SG1 systems. ${ }^{12,21 a}$ Moreover, we should emphasize that the theoretical methodology used to estimate these BDFEs has been extensively benchmarked (including against experiment) in previous studies. ${ }^{26}$

\section{Could dehydrochlorination facilitate reactivation?}

As high-level calculations suggest that the high BDFE of the $\mathrm{C}-\mathrm{O}$ bond in the PVC-SG1 alkoxyamine should completely prohibit reactivation, the presently reported experimental success is both highly surprising and intriguing. Perhaps the most straightforward explanation for the experimental success of the NMP of VC is that the SG1 radical and/or PVC-SG1 alkoxyamine participate in side-reactions, which form a more reactive intermediate alkoxyamine that is more susceptible to homolysis. If the PVC-SG1 alkoxyamine undergoes dehydrochlorination in the vicinity of the chain-ends, then the resultant allylic defect could facilitate the decomposition of the parent alkoxyamine by allowing for the elimination of a stable allylic PVC radical. Indeed, theoretical calculations indicate that two possible dehydrochlorinated PVC-SG1 structures possess much lower $\mathrm{C}-\mathrm{O}$ bond BDFEs and would be able to effectively (re)activate chain growth (Figure 7), even at low temperatures $\left(42^{\circ} \mathrm{C}\right)$.

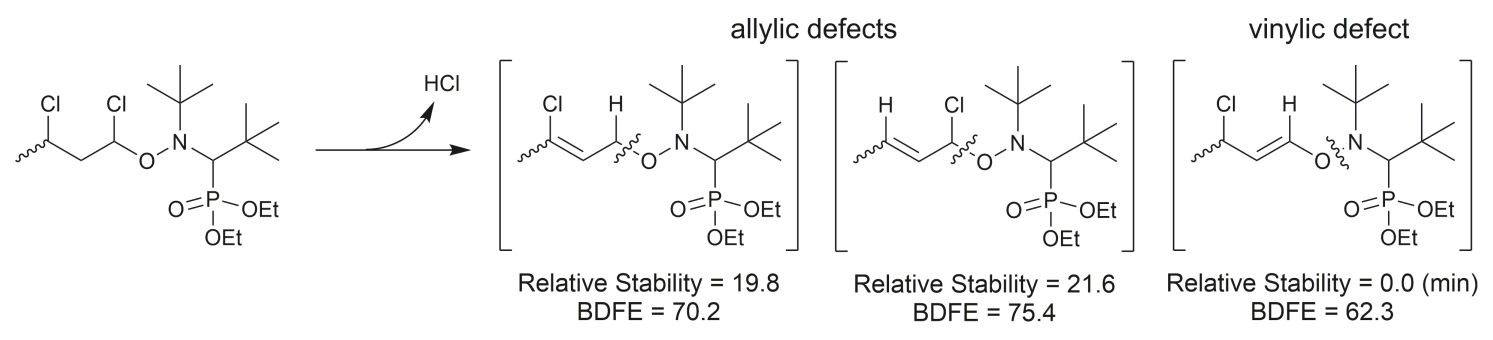

Figure 7. Possible dehydrochlorinated PVC-SG1 structures, with relative stabilities of the alkenes. BDFEs of the marked bond and relative alkene stability calculated at $40{ }^{\circ} \mathrm{C}$ are given in $\mathrm{kJ} \mathrm{mol}^{-1}$. 
Unfortunately, the exact mechanistic details of any potential dehydrochlorination reactions are currently unclear. While dehydrochlorination of unstabilized PVC is well noted at high temperatures $\left(>150{ }^{\circ} \mathrm{C}\right),{ }^{20}$ the conditions used in this polymerization are obviously much milder. However, it should be noted that amines can facilitate dehydrochlorination of PVC at lower temperatures $\left(\sim 80{ }^{\circ} \mathrm{C}\right),{ }^{35}$ and so it is possible that the SG1 is selectively mediating the dehydrochlorination mechanism in the vicinity of the chain-end. In its favour, is the absence of competing reactions in the otherwise stable PVC-SG1. Once the unsaturated defect is formed, the alkoxyamine can undergo homolysis and, given the low radical concentration, undergo several propagation steps before being trapped again by the SG1.

However, a potential problem with the mechanism is the possibility of competitively generating a vinylic PVC-SG1 structure. The $\mathrm{O}-\mathrm{N}$ bond in this vinylic structure is actually less stable than the $\mathrm{C}-\mathrm{O}$ bond of either allylic structure. If both defects form competitively, $\mathrm{O}-\mathrm{N}$ homolysis would irreversibly decompose SG1 radicals into aminyl radicals and the resulting polymerization would be poorly controlled. While the low polydispersity of the PVC obtained in the present work $(\nexists=1.5)$ is unprecedented, it is significantly above that of an optimized NMP for a less reactive monomer $(\nexists<1.2)$, and formation of vinylic groups may be a possible reason for this result. The low

concentration of $\mathrm{C}=\mathrm{C}$ defect structures detected by ${ }^{1} \mathrm{H}-\mathrm{NMR}$ in the resulting PVC may simply reflect the reversibility of the dehydrochlorination reaction under these conditions. However, we should also caution that there is limited evidence for this dehydrochlorination mechanism and so this mechanism is quite tentative. Indeed, more detailed mechanistic studies of this remarkable and surprising polymerization are currently underway.

\section{Conclusions}

The SG1-mediated polymerization of VC initiated by the BlocBuilder alkoxyamine was successfully performed at low temperatures (e.g., 30 and $42^{\circ} \mathrm{C}$ ) and led to improved control on the resulting PVC compared to early results in the literature using other nitroxide structures. The structural characterizations ( ${ }^{1} \mathrm{H}-\mathrm{NMR}$ and $\left.{ }^{31} \mathrm{P}-\mathrm{NMR}\right)$ suggested the existence of very small content of structural defects and the high preservation of the 
chain-end functionalities. PVC-SG1 macroinitiators were successfully used in chain extension experiments to produce different PVC-based diblock copolymers. This work is of significant important as it could open the door to various macromolecular architectures comprising PVC segments using the NMP techniques and all its benefits compared to other RDRP methods. Further experimental and computational studies are required for complete understanding of the mechanism of this remarkable low temperature "NMP" of VC monomer.

\section{ASSOCIATED CONTENT}

\section{Supporting Information}

${ }^{1} \mathrm{H}-\mathrm{NMR}$ spectra of PVC- $b$-PMMA and PVC- $b$-P(MMA-co-S) block copolymers; and complete computational data. This material is available free of charge via the Internet at http://pubs.acs.org.

\section{AUTHOR INFORMATION}

\section{Corresponding Author}

*E-mail: tamazguliasvili@yahoo.com (T.G.); julien.nicolas@u-psud.fr （J.N.); michelle.coote@anu.edu.au (M.L.C.); jcoelho@eq.uc.pt (J.F.J.C.).

\section{Notes}

The authors declare no competing financial interest.

\section{ACKNOWLEDGMENTS}

Carlos M. R. Abreu acknowledges FTC-MCTES for his Ph.D. scholarship (SFRH/BD/88528/2012). Patrícia V. Mendonça acknowledges FTC-MCTES for her Ph.D. scholarship (SFRH/BD/69152/2010). The ${ }^{1} \mathrm{H}$ NMR and ${ }^{31} \mathrm{P}$ NMR data were obtained at the Nuclear Magnetic Resonance Laboratory of the Coimbra Chemistry Centre (http://www.nmrccc.uc.pt), University of Coimbra, supported in part by Grant 
REEQ/481/QUI/2006 from FCT, POCI-2010, and FEDER, Portugal. Michelle L. Coote gratefully acknowledges generous allocations of supercomputing time on the National Facility of the Australian National Computational Infrastructure, and financial support from the Australian Research Council.

\section{References}

(1) (a) Nicolas, J.; Guillaneuf, Y.; Lefay, C.; Bertin, D.; Gigmes, D.; Charleux, B. Prog. Polym. Sci. 2013, 38, 63(b) Moad, G.; Rizzardo, E.; Thang, S. H. Aust. J. Chem. 2012, 65, 985(c) Moad, G.; Rizzardo, E.; Thang, S. H. Aust. J. Chem. 2009, 62, 1402(d) Perrier, S.; Takolpuckdee, P.; Mars, C. A. Macromolecules 2005, 38, 2033(e) Matyjaszewski, K.; Xia, J. Chem. Rev. 2001, 101, 2921(f) Kamigaito, M.; Ando, T.; Sawamoto, M. Chem. Rev. 2001, 101, 3689.

(2) (a) Matyjaszewski, K. Macromolecules 2012, 45, 4015(b) Wang, J.-S.; Matyjaszewski, K. J. Amer. Chem. Soc. 1995, 117, 5614.

(3) Chiefari, J.; Chong, Y. K.; Ercole, F.; Krstina, J.; Jeffery, J.; Le, T. P. T.; Mayadunne, R. T. A.; Meijs, G. F.; Moad, C. L.; Moas, G.; Rizzardo, E.; Thang, S. H. Macromolecules 1998, 31, 5559.

(4) Georges, M. K.; Veregin, R. P. N.; Kazmaier, P. M.; Hamer, G. K. Macromolecules 1993, 26, 2987.

(5) (a) Matyjaszewski, K.; Tsarevsky, N. V. J. Amer. Chem. Soc. 2014, 136, 6513(b) Ando, T.; Kamigaito, M.; Sawamoto, M. Kobunshi Ronbunshu 2002, 59, 199.

(6) Tsarevsky, N. V.; Matyjaszewski, K. Chem. Rev. 2007, 107, 2270.

(7) (a) Maximiano, P.; Mendes, J. P.; Mendonça, P. V.; Abreu, C. M. R.; Guliashvili, T.; Serra, A. C.; Coelho, J. F. J. J. Polym. Sci., Part A: Polym. Chem. 2015, DOI: 10.1002/pola.27736(b) Abreu, C. M. R.; Serra, A. C.; Popov, A.; Matyjaszewski, K.; Guliashvili, T.; Coelho, J. F. J. Polym. Chem. 2013(c) Abreu, C. M. R.; Mendonça, P. V.; Serra, A. C.; Coelho, J. F. J.; Popov, A. V.; Guliashvili, T. Macromol. Chem. Phys. 2012, 213, 1677(d) Chenal, M.; Mura, S.; Marchal, C.; Gigmes, D.; Charleux, B.; Fattal, E.; Couvreur, P.; Nicolas, J. Macromolecules 2010, 43, 9291.

(8) (a) Mendes, J. P.; Branco, F.; Abreu, C. M. R.; Mendonça, P. V.; Serra, A. C.; Popov, A. V.; Guliashvili, T.; Coelho, J. F. J. ACS Macro Lett. 2014, 3, 858(b) Abreu, C. M. R.; Mendonca, P. V.; Serra, A. C.; Popov, A. V.; Matyjaszewski, K.; Guliashvili, T.; Coelho, J. F. J. ACS Macro Lett. 2012, 1, 1308.

(9) Global demand for PVC to rise by about 3.2\%/year to 2021; Additives for Polymers: http://dx.doi.org/10.1016/S0306-3747(14)70175-7, 2014.

(10) Abreu, C. M. R.; Mendonça, P. V.; Serra, A. C.; Coelho, J. F. J.; Popov, A. V.; Gryn'ova, G.; Coote, M. L.; Guliashvili, T. Macromolecules 2012, 45, 2200.

(11) Odian, G. In Principles of Polymerization; John Wiley \& Sons, Inc., 2004.

(12) Nicolas, J.; Dire, C.; Mueller, L.; Belleney, J.; Charleux, B.; Marque, S. R. A.; Bertin, D.; Magnet, S.; Couvreur, L. Macromolecules 2006, 39, 8274.

(13) Ayrey, G.; Haynes, A. C. Makromol. Chem. 1974, 175, 1463.

(14) Percec, V.; Popov, A. V.; Ramirez-Castillo, E.; Coelho, J. F. J.; Hinojosa-Falcon, L. A. J. Polym. Sci., Part A: Polym. Chem. 2004, 42, 6267. 
(15) (a) Hatano, T.; Rosen, B. M.; Percec, V. J. Polym. Sci., Part A: Polym. Chem. 2010, 48, 164(b) Sienkowska, M. J.; Rosen, B. M.; Percec, V. J. Polym. Sci., Part A: Polym. Chem. 2009, 47, 4130(c) Percec, V.; Guliashvili, T.; Ladislaw, J. S.; Wistrand, A.; Stjerndahl, A.; Sienkowska, M. J.; Monteiro, M. J.; Sahoo, S. J. Amer. Chem. Soc. 2006, 128, 14156.

(16) (a) Coelho, J. F. J.; Fonseca, A. C.; Gonçalves, P. M.; Popov, A. V.; Gil, M. H. Chem. Eng. Sci. 2012, 69, 122(b) Coelho, J. F. J.; Fonseca, A. C.; Gonçalves, P. M. F. O.; Popov, A. V.; Gil, M. H. Polym. J. 2011, 52, 2998(c) Coelho, J. F. J.; Fonseca, A. C.; Góis, J. R.; Gonçalves, P. M.; Popov, A. V.; Gil, M. H. Chem. Eng. J. 2011, 169, 399(d) Coelho, J. F. J.; Mendonca, P. V.; Popov, A. V.; Percec, V.; Gonçalves, P. M.; Gil, M. H. J. Polym. Sci., Part A: Polym. Chem. 2009, 47, 7021(e) Coelho, J. F. J.; Carreira, M.; Popov, A. V.; Gonçalves, P. M.; Gil, M. H. Eur. Polym. J. 2006, 42, 2313(f) Coelho, J. F. J.; Carreira, M.; Gonçalves, P. M.; Popov, A. V.; Gil, M. H. J. Vinyl Addit. Technol. 2006, 12, 156(g) Percec, V.; Popov, A. V.; Ramirez-Castillo, E.; Coelho, J. F. J.; Hinojosa-Falcon, L. A. J. Polym. Sci., Part A: Polym. Chem. 2005, 43, 779(h) Percec, V.; Guliashvili, T.; Popov, A. V. J. Polym. Sci., Part A: Polym. Chem. 2005, 43, 1948(i) Percec, V.; Popov, A. V.; Ramirez-Castillo, E.; Weichold, O. J. Polym. Sci., Part A: Polym. Chem. 2004, 42, 6364(j) Percec, V.; Popov, A. V.; Ramirez-Castillo, E.; Weichold, O. J. Polym. Sci., Part A: Polym. Chem. 2003, 41, 3283(k) Percec, V.; Popov, A. V.; Ramirez-Castillo, E.; Monteiro, M.; Barboiu, B.; Weichold, O.; Asandei, A. D.; Mitchell, C. M. J. Amer. Chem. Soc. 2002, 124, 4940.

(17) (a) Piette, Y.; Debuigne, A.; Bodart, V.; Willet, N.; Duwez, A.-S.; Jerome, C.; Detrembleur, C. Polym. Chem. 2013, 4, 1685(b) Piette, Y.; Debuigne, A.; Jerome, C.; Bodart, V.; Poli, R.; Detrembleur, C. Polym. Chem. 2012, 3, 2880.

(18) (a) Braun, D. J. Vinyl Addit. Technol. 2005, 11, 86(b) Wannemacher, T.; Braun, D.; Pfaendner, R. Macromol. Symp. 2003, 202, 11.

(19) (a) Starnes, W. H., Jr. J. Polym. Sci., Part A: Polym. Chem. 2005, 43, 2451(b) Starnes, W. H., Jr.; Ge, X. Macromolecules 2004, 37, 352.

(20) Starnes, W. H. Prog. Polym. Sci. 2002, 27, 2133.

(21) (a) Chauvin, F.; Dufils, P.-E.; Gigmes, D.; Guillaneuf, Y.; Marque, S. R. A.; Tordo, P.; Bertin, D. Macromolecules 2006, 39, 5238(b) Nicolas, J.; Charleux, B.; Guerret, O.; Magnet, S. Macromolecules 2004, 37, 4453.

(22) Bagryanskaya, E. G.; Marque, S. R. A. Chem. Rev. 2014, 114, 5011.

(23) Henry, D. J.; Sullivan, M. B.; Radom, L. J. Chem. Phys. 2003, 118, 4849.

(24) Zhao, Y.; Truhlar, D. Theor. Chem. Acc. 2008, 120, 215.

(25) Marenich, A. V.; Cramer, C. J.; Truhlar, D. G. J. Phys. Chem. B 2009, 113, 6378.

(26) (a) Gryn'ova, G.; Marshall, D. L.; Blanksby, S. J.; Coote, M. L. Nat. Chem. 2013, 5, 474(b) Hodgson, J. L.; Yeh Lin, C.; Coote, M. L.; Marque, S. R. A.; Matyjaszewski, K. Macromolecules 2010, 43, 3728(c) Hodgson, J. L.; Roskop, L. B.; Gordon, M. S.; Lin, C. Y.; Coote, M. L. J. Phys. Chem. A 2010, 114, 10458(d) Coote, M. L.; Lin, C. Y.; Beckwith, A. L. J.; Zavitsas, A. A. Phys. Chem. Chem. Phys. 2010, 12, 9597.

(27) Frisch, M. J.; Trucks, G. W.; Schlegel, H. B.; Scuseria, G. E.; Robb, M. A.; Cheeseman, J. R.; Scalmani, G.; Barone, V.; Mennucci, B.; Petersson, G. A.; Nakatsuji, H.; Caricato, M.; Li, X.; Hratchian, H. P.; Izmaylov, A. F.; Bloino, J.; Zheng, G.; Sonnenberg, J. L.; Hada, M.; Ehara, M.; Toyota, K.; Fukuda, R.; Hasegawa, J.; Ishida, M.; Nakajima, T.; Honda, Y.; Kitao, O.; Nakai, H.; Vreven, T.; Montgomery Jr., J. A.; Peralta, J. E.; Ogliaro, F.; Bearpark, M.; Heyd, J. J.; Brothers, E.; Kudin, K. N.; Staroverov, V. N.; Kobayashi, R.; Normand, J.; 
Raghavachari, K.; Rendell, A.; Burant, J. C.; Iyengar, S. S.; Tomasi, J.; Cossi, M.; Rega, N.; Millam, N. J.; Klene, M.; Knox, J. E.; Cross, J. B.; Bakken, V.; Adamo, C.; Jaramillo, J.; Gomperts, R.; Stratmann, R. E.; Yazyev, O.; Austin, A. J.; Cammi, R.; Pomelli, C.; Ochterski, J. W.; Martin, R. L.; Morokuma, K.; Zakrzewski, V. G.; Voth, G. A.; Salvador, P.; Dannenberg, J. J.; Dapprich, S.; Daniels, A. D.; Farkas, Ö.; Foresman, J. B.; Ortiz, J. V.; Cioslowski, J.; Fox, D. J. G. Gaussian 09; Gaussian, Inc.: Wallingford CT, USA, 2009.

(28) (a) Werner, H.-J.; Knowles, P. J.; Knizia, G.; Manby, F. R.; Schütz, M.; Celani, P.; Korona, T.; Lindh, R.; Mitrushenkov, A.; Rauhut, G.; Shamasundar, K. R.; Adler, T. B.; Amos, R. D.; Bernhardsson, A.; Berning, A.; Cooper, D. L.; Deegan, M. J. O.; Dobbyn, A. J.; Eckert, F.; Goll, E.; Hampel, C.; Hesselmann, A.; Hetzer, G.; Hrenar, T.; Jansen, G.; Köppl, C.; Liu, Y.; Lloyd, A. W.; Mata, R. A.; May, A. J.; McNicholas, S. J.; Meyer, W.; Mura, M. E.; Nicklass, A.; O'Neill, D. P.; Palmieri, P.; Peng, D.; Pflüger, K.; Pitzer, R.; Reiher, M.; Shiozaki, T.; Stoll, H.; Stone, A. J.; Tarroni, R.; Thorsteinsson, T.; Wang, M. MOLPRO, version 2012.1, a package of ab initio programs: see http://www.molpro.net., 2012(b) Werner, H.-J.; Knowles, P. J.; Knizia, G.; Manby, F. R.; Schütz, M. WIREs Comput. Mol. Sci. 2012, 2, 242.

(29) Guégain, E.; Guillaneuf, Y.; Nicolas, J. Macromol. Rapid Commun. 2015, 36, 1227.

(30) Mendes, J. P.; Branco, F.; Abreu, C. M. R.; Mendonça, P. V.; Popov, A. V.; Guliashvili, T.; Serra, A. C.; Coelho, J. F. J. ACS Macro Lett. 2014, 3, 544.

(31) Nicolas, J.; Couvreur, P.; Charleux, B. Macromolecules 2008, 41, 3758.

(32) (a) Delplace, V.; Harrisson, S.; Ho, H. T.; Tardy, A.; Guillaneuf, Y.; Pascual, S.; Fontaine, L.; Nicolas, J. Macromolecules 2015, 48, 2087(b) Delplace, V.; Harrisson, S.; Tardy, A.; Gigmes, D.; Guillaneuf, Y.; Nicolas, J. Macromol. Rapid Commun. 2014, 35, 484.

(33) Ruehl, J.; Hill, N. L.; Walter, E. D.; Millhauser, G.; Braslau, R. Macromolecules 2008, 41, 1972.

(34) Gryn'ova, G.; Lin, C. Y.; Coote, M. L. Polym. Chem. 2013, 4, 3744.

(35) Bowley, H. J.; Gerrard, D. L.; Biggin, I. S. J. Vinyl Addit. Technol. 1988, 10, 50.

Insert Table of Contents Graphic and Synopsis Here

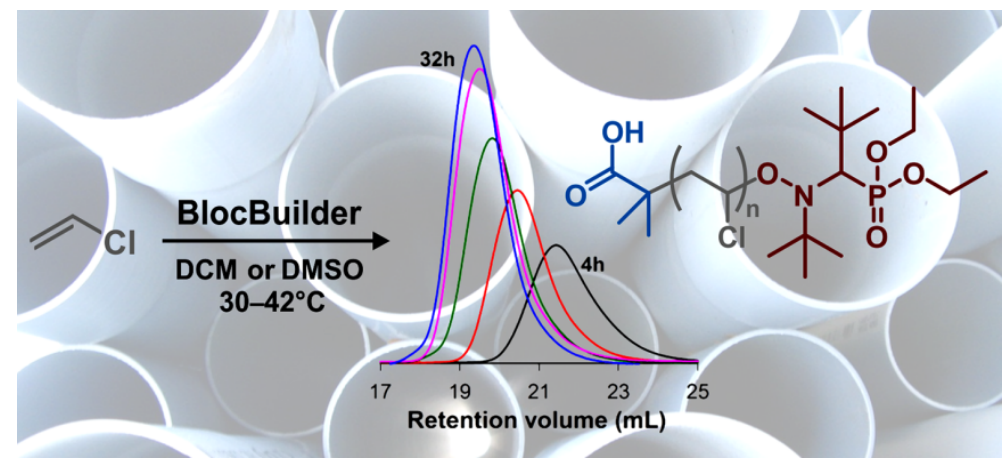

